\title{
EFFECTS OF WETTING MEDIA CATTLE BLOOD, RICE GRUEL AND WATER ON THE YIELD AND AMINO ACID COMPOSITION OF TUBIFICID WORMS
}

\author{
MAHMUD HASAN", MD. INJA-MAMUN HAQUE, NAFIA AKTER, MOHAMMAD \\ SHAMSUR RAHMAN AND AFROZA SULTANA ETI \\ Department of Fisheries, University of Dhaka, Dhaka-1000, Bangladesh
}

\begin{abstract}
The effects of three wetting media (cattle blood, rice gruel and subsurface clean water) of the culture media ingredients (a mixture of mustard oil cake, soybean meal and mud) on the yield and amino acid composition of tubificid worms cultured on a pilot scale in a fish farm for 42 days were evaluated. The worm yields were in the order: cattle blood wetted media $\left(683.68 \pm 3.86 \mathrm{mg} / \mathrm{cm}^{2}\right)$, rice gruel $\left(615.63 \pm 3.66 \mathrm{mg} / \mathrm{cm}^{2}\right)$, water $(584.38 \pm 1.41$ $\left.\mathrm{mg} / \mathrm{cm}^{2}\right)$. Lysine, arginine and leucine were the most prevalent of the eight essential amino acids in worms cultured in the media wetted in cattle blood medium. The results suggested that a mixture of $40 \%$ mustard oil cake, $30 \%$ soybean meal and $30 \%$ mud can be used for the commercial culture of tubificid worms as live fish food. The tubificid worms showed high level of amino acids suitable for fish that require a high content of dietary amino acids.
\end{abstract}

Key words: Wetting media, Yield, Amino acid composition, Tubifiecid worms

\section{Introduction}

Tubificids are aquatic worms of the family Tubificidae of phylum Annelida. These are also known as sludge worms that can live in a polluted environment (Mariom and Mollah 2012). In Bangladesh, tubificid worms have been used as live feed in the rearing of catfish fry up to the fingerling stage. Currently, since tubificid worms are not cultured in Bangladesh, they are collected from drains, ponds or rivers to meet the demand of the catfish hatcheries.

Catfishes account for nearly $12.79 \%$ of the total fish production of Bangladesh (FRSS 2016). The striped catfish pangus, Pangasianodon hypophthalmus (Sauvage 1878) is the most common species used in aquaculture in Bangladesh, accounting for nearly $11.04 \%$ of the total fish production (FRSS 2016). Farming of high valued catfishes such as the stinging catfish Heteropneus tesfossilis (Bloch 1794), the walking catfish Clarias batrachus (Linnaeus 1758) and pabda Ompok spp. is becoming increasingly popular because of high market demand. Farming of these catfishes requires live food for the nursing of spawn to fry and the rearing of fry to fingerlings stages. Catfish spawn are fed blended tubificid worms while the fry is given the entire worm. Sustainable catfish production requires a reliable supply of good quality hygienic fish seed, which depends

*Author for correspondence: <mhasan@du.ac.bd>. 
upon a reliable supply of hygienically produced live fish food such as tubificid worms. There is insufficient supply of wild-harvested worms and it does not meet the hygienic standard as feed for larval stages of fish (Mollah et al. 2009).

The culture of tubificid worms on a fish farm by using local media ingredients such as soybean meal (SBM), mustard oil cake (MOC), wheat bran (WB) and no- or low-cost wetting medium, such as blood from slaughtered cattle and rice gruel, is not a practice in Bangladesh. To enhance and sustain the rapidly growing catfish aquaculture in Bangladesh, blood from slaughtered cattle and rice gruel could be used to produce tubificid worms as live feed to ensure a reliable supply of good quality catfish seed through nursing and rearing practices. Thousands of cattle are slaughtered daily in every city and town in Bangladesh. However, the slaughtered animals' blood is disposed of instead of being harvested.

Rice gruel is produced in every household, restaurant and student dormitory and is thrown away. The usefulness of rice gruel as a wetting medium for media ingredients for the enhanced production of tubificid worms has been demonstrated by Mariom and Mollah (2012), Hossain et al. (2012) and Mariom and Mollah (2013).

Soybean meal and mustard oil cake have been widely used in fish feed and contains 40 $50 \%$ crude protein but lacks cystidine, methionine, calcium, phosphorus and vitamin B complex (Hasan 2003). Mustard oil cake contain 28 - 38\% crude protein and all commonly found amino acids (Sarker et al. 2015).

The commercial culture of tubificid worms on the fish farms could sustain the production of catfish seed in the hatchery provided the supply of worms is reliable. Furthermore, cultured worms will reduce the risk of outbreaks of typhoid and cholera among the wild worm collectors caused by Salmonella and Vibrio spp. if the worms are harvested from sewage fed drains and ponds, lakes and rivers (Mandal et al. 2018).

Ahmed and Mollah (1992) suggested 20\% MOC, 35\% WB, 25\% cow dung (CD) and 20\% sand as a suitable medium for the sustainable growth of tubificid worms. However, Mollah et al. (2012) obtained higher production by using a mixture of 35\% MOC, $20 \% \mathrm{WB}, 25 \%$ $\mathrm{CD}$ and 20\% sand. Mariom and Mollah (2012) suggested using a mixture of 20\% MOC, $20 \% \mathrm{WB}, 30 \% \mathrm{SBM}, 20 \% \mathrm{CD}$ and $10 \%$ sand as the best medium to culture tubificid worms. Hossain et al. (2012) had similar findings as reported by Mariom and Mollah (2012). Mandal et al. (2016) suggest that rice mill sludge, dairy sludge and raw cattle dung can also be used as culture media in producing tubifex worms. However, all of these studies were done at on-station/on-farm. Therefore, a study for the purpose of pilot culture revealing the real field condition that is called off-farm/off-station is necessary to 
determine the effects of wetting media of the culture media ingredients on the yield and amino acid composition of the tubificid worms.

The objectives of this off farm study were to determine the effects of wetting media on the yield of tubificid worms and to determine the effects of culture media ingredients and wetting media on the proximate and amino acid composition of both the media and the tubificid worms.

\section{Materials and Methods}

Experimental tubificid worms and procedure: Wild-harvested tubificid worms were bought from local collectors and used as study animals. After harvest, the worms were cleaned by subsurface clean water. Before inoculating into the culture media, the worms were conditioned by holding them in a tray in the presence of slow water flow for 24 hours. The study was conducted in 2016 at the Maa Fatema Fish Hatchery, Chachra, Dalmil, Jessore, Bangladesh.

Experimental system: Nine newly constructed cement raceways measuring $72 \times 80 \times 10$ $\mathrm{cm}$ were used as culture system. Each culture unit was provided with continuous water flow through a porous 1 inch diameter uPVC spray bar. The water flow rate was maintained to sustain a dissolved oxygen concentration above $4 \mathrm{mg} / \mathrm{l}$.

Study design: This was a one factorial study in triplicates. The wetting medium was the only experimental variable. Cattle blood, rice gruel and clean water were used as wetting media. The worm yield was the indicator variable. The amino acid profiles of the wild and cultured worms and the media ingredients wetted in cattle blood, rice gruel and subsurface clean water were also measured by automatic amino acid analyzer (Hitachi L-8800, Tokyo, Japan).

Media combination: The type and quantity of the culture media ingredients used in the present study were determined through a series of experiments. Initially, a mixture of $20 \%$ WB, 30\% SBM, 20\% MOC, $20 \% \mathrm{CD}$ and $10 \%$ sand was tested for the commercial culture of worms on a fish farm as suggested by Mariom and Mollah (2012) and Hossain et al. (2012). However, CD was found to enhance moulds - like jelly growth. Since wheat bran did not decompose over 7 days of wetting, WB and CD were discarded. Sand was also discarded as mud was found to be a better medium to enhance the growth of the worms. Therefore, 30\% SBM, $40 \%$ MOC and 30\% mud were used as the culture media ingredients in the present study (Table 1).

Collection of media ingredients and a wetting medium: Locally available SBM and MOC were bought from local markets of Jessore, Bangladesh. Blood was collected from a 
slaughter-house and rice gruel was obtained from a restaurant. Mud was collected from a pond nearby Maa Fatema Fish Hatchery.

Media supply: Three treatments composed of nine culture units each of which $\left(5760 \mathrm{~cm}^{2}\right)$ was given $1440 \mathrm{~g}$ media $\left(250 \mathrm{mg} \mathrm{cm}^{-2}\right)$ wetted in about 3 litre blood rice gruel and water for 7 days as suggested by Mariom and Mollah (2012) and Hossain et al. (2012). Soybean meal (576 g) and mustard oil cake (432 g) were mixed and wetted with blood in three plastic bowls for 7 days. Similar quantities of media ingredients were also wetted with rice gruel and water in six plastic bowls. The media ingredients in each bowl were mixed well by hand twice daily. Mud (576 g) was applied after one day later of inoculation. Each culture unit was filled with water until it was overflowing.

Culture technology: A batch culture system was used. The system was inoculated once, and all the worms were harvested after 42 days of culture.

Inoculation of the worms: The culture system was inoculated with wild-harvested worms at a density of $50 \mathrm{mg} \mathrm{cm}$, which had been determined via a series of trial experiments. The worms were homogenously spread by hand over the medium in each culture unit.

Renewal of the culture system: Each culture unit was renewed with culture media wetted for 7 days once at $50 \mathrm{mg} \mathrm{cm}^{-2}$ during the first two weeks and twice during the next four weeks. The water flow was stopped before the media was applied and resumed 10 minutes later.

Water flow: The water flow rate was adjusted to maintain the dissolved oxygen concentration (DO) above $4 \mathrm{mg} / \mathrm{l}$. Each culture unit was connected to a separate inlet and outlet. The DO was measured with a portable meter (Model: HACH sension 6, Loveland, CO, USA) at 10 a.m.

Table 1. The combinations of culture media ingredients wetted in blood, rice gruel and water used to culture tubificid worms in nine experimental units of culture in three treatments.

\begin{tabular}{llll}
\hline Ingredients & \multicolumn{3}{c}{ Per cent ingredients in three treatments } \\
\cline { 2 - 4 } used & Cattle blood & Rice gruel & Water \\
\hline Soybean meal & 30 & 30 & 30 \\
Mustard oil cake & 40 & 40 & 40 \\
Cattle blood & About 3 litre & - & - \\
Rice gruel & - & About 3 litre & - \\
Subsurface water & - & - & About 3 litre \\
Mud & 30 & 30 & 30 \\
\hline
\end{tabular}

Harvest: All the worms from each culture unit were harvested by sieving with a nylon net similar to Mandal et al. (2018). The harvested worms were washed in clean water. The 
clean worms were dried with blotting paper by holding them in a plastic bowl and weighed on an electronic balance (Shimadzu, Japan).

Laboratory assays: Moisture, ash, protein, fat, fibre and the carbohydrate in the media ingredients, the culture media ingredients wetted in blood, rice gruel and water, and cultured worms in the three wetting media (Table 2-3) were analysed by following the method described by Cheng et al. (2016).

The amino acid profiles of the media ingredients wetted in water, rice gruel and cattle blood (Table 4) and wild and cultured worms (Table 6) were determined using an automatic amino acid analyzer (Hitachi L-8800, Tokyo, Japan) in combination with postcolumn derivatization with ninhydrin; which was done at the Bangladesh Council of Scientific and Industrial Research Laboratory following the method described by Cheng et al. (2016). In brief, the determination of cystine and methionine was done after performic acid oxidation before hydrolysis. To obtain methionine sulphone and cysteic acid, the samples were oxidised with performic acid at $-10^{\circ} \mathrm{C}$ for $3 \mathrm{hrs}$ and afterwards freeze-dried twice with deionized water. The decomposition of surplus performic acid was done by adding sodium metabisulfite and consequently, the hydrolysis $\left(6 \mathrm{~N} \mathrm{HCl}, 110^{\circ} \mathrm{C}\right.$ for $\left.24 \mathrm{hrs}\right)$ of the sample was performed under vacuum. The sodium citrate buffer $(\mathrm{pH} 2.2)$ dissolved the hydrolysate. Ion exchange chromatography (at $570 \mathrm{~nm}$ ) was used to separate individual amino acid components. The colorimetric method was used to determine the tryptophan level following the alkaline hydrolysis of each sample.

The chemical composition of the mud was also analyzed following the method described by Huq and Alam (2005).

Data analysis: All per cent data were square root-transformed before analysis. Data were analysed by a one-way ANOVA followed by Tukey's HSD post hoc for multiple comparison test. SPSS version 20.0 was used to analyze the data. The level of significance was reported as $\mathrm{p}<0.05$.

Table 2. Nutrient composition of the media ingredients soybean meal and mustard oil cake and wetting medium blood and rice gruel.

\begin{tabular}{lcccc}
\hline Ingredients & \multicolumn{4}{c}{ Composition $(\%)$} \\
\cline { 2 - 5 } (Dry matter basis) & Soybean meal & Mustard oil cake & Cattle blood & Rice gruel \\
\hline Protein & 49.15 & 35.11 & 81.83 & 7.89 \\
Fat & 5.76 & 15.11 & 1.68 & 4.45 \\
Ash & 7.50 & 11.24 & 4.14 & 3.38 \\
Fiber & 1.0 & 1.0 & 1.0 & 1.45 \\
Carbohydrate & 36.58 & 37.56 & 11.93 & 81.38 \\
Total & 100 & 100 & 100 & 100 \\
\hline
\end{tabular}


Table 3. Nutrient composition of the mixed media ingredients wetted in blood, rice gruel and water sampled after 7 days of wetting.

\begin{tabular}{lccc}
\hline Ingredients & \multicolumn{3}{c}{ Composition of the media wetted in blood, rice gruel and water } \\
\cline { 2 - 4 } (Dry matter basis) & Cattle blood & Rice gruel & Water \\
\hline Protein & 58.16 & 46.74 & 43.67 \\
Fat & 13.43 & 15.43 & 17.60 \\
Ash & 8.27 & 8.71 & 2.90 \\
Fiber & 1.0 & 1.0 & 1.0 \\
Carbohydrate & 19.14 & 28.12 & 34.83 \\
Total & 100 & 100 & 100 \\
\hline
\end{tabular}

\section{Results and Discussion}

Yield of tubificid worms: The highest yield of tubificid worms $\left(683.68 \pm 3.86 \mathrm{mg} / \mathrm{cm}^{2}\right)$ was harvested from the media wetted in cattle blood medium, and the lowest yield $(584.38 \pm$ $1.41 \mathrm{mg} / \mathrm{cm}^{2}$ ) was found in the media wetted with clean water medium (Fig. 1). The rice gruel wetted media gave a worm yield $\left(615.63 \pm 3.66 \mathrm{mg} / \mathrm{cm}^{2}\right)$, that was significantly different from the other two treatments.

Table 4. Amino acid profiles of the media ingredients wetted in blood, rice gruel and water sampled after 7 days of wetting.

\begin{tabular}{lccc}
\hline \multirow{2}{*}{ Amino acids } & \multicolumn{3}{c}{$\begin{array}{c}\text { Composition (\% protein) of media ingredients wetted in } \\
\text { wetting mediums water, rice gruel and blood }\end{array}$} \\
\cline { 2 - 4 } & Water & Rice gruel & Cattle blood \\
\hline Essential amino acids & 8.7 & 10.6 & 12.2 \\
Threonine & 0.88 & 1.13 & 1.15 \\
Leucine & 2.33 & 3.3 & 3.58 \\
Methionine & 4.56 & 4.92 & 5.12 \\
Lysine & 2.49 & 2.66 & 2.85 \\
Arginine & 0.81 & 0.93 & 1.06 \\
Valine & 2.80 & 3.30 & 3.93 \\
Isoleucine & 0.59 & 0.68 & 0.74 \\
Histidine & & & 6.24 \\
Non-essential amino acids & 4.72 & 5.36 & 2.85 \\
Aspartic acid & 2.30 & 2.69 & 3.75 \\
Serine & 2.32 & 3.61 & 2.67 \\
Glutamic acid & 2.36 & 2.53 & 2.99 \\
Glycine & 2.37 & 2.7 & 1.84 \\
Alanine & 1.50 & 1.74 & \\
Tyrosine & & &
\end{tabular}


The highest yield of worms cultured in the media wetted in cattle blood medium could have been due to the high amount of dietary protein (58\%) received over 42 days. A high level of worms' inoculum of $50 \mathrm{mg} / \mathrm{cm}^{2}$ might have grown and propagated quickly with a high protein level that could have played a key role in maturing and reproduction to increase the biomass. Islam et al. (2015) found a worm yield of only $256 \mathrm{mg} / \mathrm{cm}^{2}$ after 40 days of culture duration when chicken blood was used as the wetting medium with an inoculum of only $1.25 \mathrm{mg} / \mathrm{cm}^{2}$. Moreover, they cultured the worms for 70 days, which was 1.75-folds longer than the culture period of the present study. In the present study, the shorter culture period of 42 days was to reduce the cost of electricity to pump subsurface water. In addition, Islam et al. (2015) renewed the media ingredients in the system at the rate of $250 \mathrm{mg} / \mathrm{cm}^{2}$, while in the present study only $50 \mathrm{mg} / \mathrm{cm}^{2}$ was used for the first 2 weeks and $100 \mathrm{mg} / \mathrm{cm}^{2}$ during the remaining 4 weeks. Furthermore, Islam et al. (2015) used 20\% MOC, $20 \%$ wheat bran (WB), 30\% SBM, 20\% cow dung (CD) and 10\% sand, while in the present study $30 \%$ SBM, $40 \%$ MOC and $30 \%$ mud were used.

Worms were found to be evenly distributed when mud was applied one day after the media ingredients were placed. An even distribution of worms over the media ensures better media utilization. In the present study, the media requirements were 1.33-folds lower than those of Mariom and Mollah (2012), Hossain et al. (2012) and Islam et al. (2015). More worms $\left(616 \mathrm{mg} / \mathrm{cm}^{2}\right.$ over 42 -day culture duration) grew in the rice gruel wetted media, compared with the findings of Hossain et al. $\left(2012,210 \mathrm{mg} / \mathrm{cm}^{2}\right)$, Mariom and Mollah $\left(2013,430 \mathrm{mg} / \mathrm{cm}^{2}\right)$ and Islam et al. $\left(2015,256 \mathrm{mg} / \mathrm{cm}^{2}\right)$ in 40 days of culture by inoculating $5.00,1.25$ and $1.25 \mathrm{mg} / \mathrm{cm}^{2}$ worms, in cattle blood, rice gruel and water, respectively.

Proximate composition of the worms: Worms cultured in the cattle blood wetted media had $58 \%$ crude protein followed by rice gruel (55\%) and water (53\%, Table 5). Similarly, the highest level of fat $(13 \%)$ was found in the worms produced in the media wetted with cattle blood medium followed by rice gruel $(12 \%)$ and water $(11 \%)$.

Amino acid profiles of the wild and cultured worms: A total of 14 amino acids were found by hydrolysis of the samples in $\mathrm{HCl}$. All 14 amino acids were found at a significantly higher level in worms cultured in the media ingredients wetted in cattle blood medium than in the wild worms, or worms cultured in the media ingredients wetted in rice gruel and water medium (Table 6). Of the eight essential amino acids (EAA) found in the worms, lysine, arginine and leucine were found in the greatest amount in the worms cultured in the media ingredients wetted in cattle blood medium followed by wild worms and rice gruel medium. With reference to the non-essential amino acids, worms cultured in the media ingredients wetted in cattle blood medium had the greatest amount of glycine followed by values in wild worms. The amount of glycine was similar to glutamic acid in 
worms cultured in the media ingredients wetted in rice gruel medium. Alanine and glutamic acid followed similar trends.

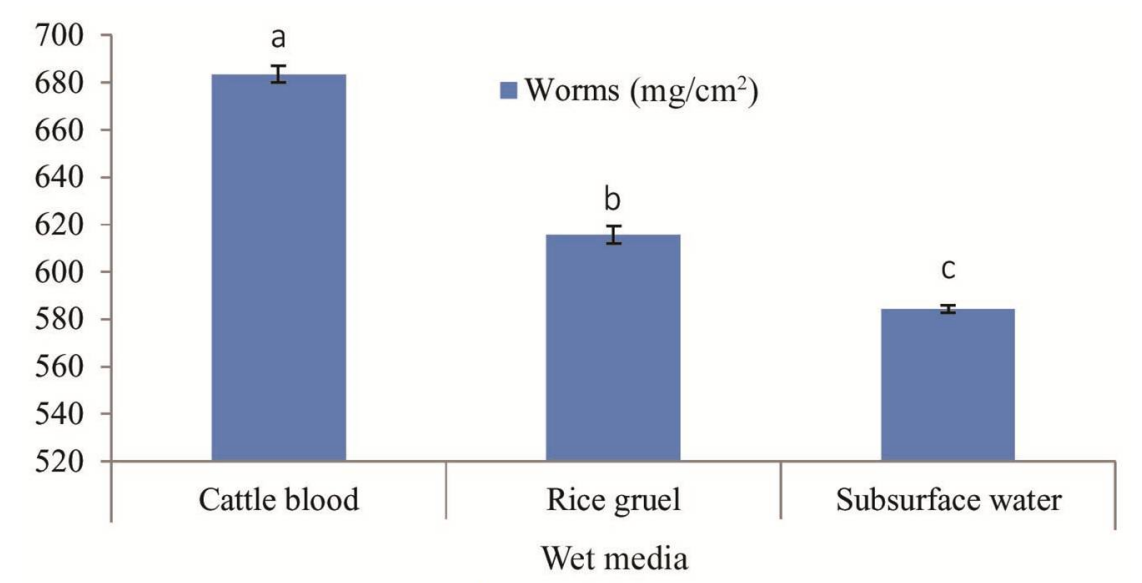

Fig. 1. Yield of tubificid worms $\left(\mathrm{mg} / \mathrm{cm}^{2}\right)$ harvested from the media wetted by cattle blood, rice gruel and subsurface water after 42-day culture in cemented culture raceway of $0.567 \mathrm{~m}^{2}$. Bars (mean \pm 1 SEM, $\mathrm{n}=3$ ) with different letters indicate significant difference (ANOVA, HSD; $\mathrm{p}<$ $0.05)$.

Chemical composition of mud: The mud contained $0.51 \%$ nitrogen, $52.70 \mathrm{ppm}$ phosphorus and $112.28 \mathrm{ppm}$ potassium.

Table 5. Proximate composition of the worms.

\begin{tabular}{lccc}
\hline \multirow{2}{*}{$\begin{array}{l}\text { Composition } \\
\text { (Dry matter basis) }\end{array}$} & \multicolumn{2}{c}{$\begin{array}{c}\text { Composition (\%) of worms produced in the culture media wetted } \\
\text { in wetting mediums cattleblood (1), rice gruel (2) and water (3) }\end{array}$} \\
\cline { 2 - 4 } & 1 & 2 & 3 \\
\hline Protein & 58.20 & 55.50 & 53.24 \\
Fat & 13.20 & 11.68 & 11.04 \\
Ash & 5.02 & 3.50 & 5.07 \\
Fiber & 4.24 & 3.31 & 3.29 \\
Carbohydrate & 19.34 & 26.01 & 27.36 \\
Total & 100 & 100 & 100 \\
\hline
\end{tabular}

All eight EAAs found in the worms cultured in cattle blood wetted media are suitable for raising fish that requires high protein $(55 \%)$ in the diet. Fish need $2.37 \%$ arginine, $1.00 \%$ histidine, $1.54 \%$ isoleucine, $2.81 \%$ leucine, $3.25 \%$ lysine, $1.06 \%$ methionine, $1.77 \%$ threonine and $1.83 \%$ valine if the diet contains protein as high as 55\% (Tacon 1987). The 
high level of all 14 amino acids observed in the worms could have resulted because of the high level of dietary amino acids in culture media ingredients wetted in wetting medium cattle blood. Khan and Abidi (2014) have demonstrated that stinging catfish fry require $1.6 \%$ dietary histidine for maximum growth. Juvenile giant croaker Nibea japonica (Temminck and Schlegel 1843) had highest growth rate when fed feed with arginine $5.13 \%$, histidine $2.91 \%$, isoleucine $4.36 \%$, leucine $8.94 \%$, lysine $8.08 \%$, methionine $2.86 \%$, phenylalanine $4.58 \%$, threonine $4.30 \%$, tryptophan $1.28 \%$ and valine $5.51 \%$ (Cheng et al. 2016). The per cent composition of the amino acids found in the worms rose on media ingredients wetted in cattle blood and rice gruel particularly in cattle blood could be used in raising fishes that require high level of amino acids.

Table 6. Amino acid profiles of the wild and cultured worms in which media ingredients were wetted in cattle blood, rice gruel and subsurface clean water.

\begin{tabular}{lllll}
\hline \multicolumn{1}{c}{$\begin{array}{c}\text { Amino acids }(\% \text { of } \\
\text { protein })\end{array}$} & \multicolumn{4}{c}{ Types of worms raised in the culture media wetted in } \\
\cline { 2 - 5 } & Wild & Blood & Rice gruel & Water \\
\hline Essential amino acids & & & & \\
Threonine & $1.70 \pm 0.01^{\mathrm{d}}$ & $3.62 \pm 0.03^{\mathrm{a}}$ & $2.71 \pm 0.02^{\mathrm{b}}$ & $2.60 \pm 0.02^{\mathrm{c}}$ \\
Leucine & $4.50 \pm 0.12^{\mathrm{b}}$ & $5.19 \pm 0.21^{\mathrm{a}}$ & $4.20 \pm 0.08^{\mathrm{c}}$ & $3.80 \pm 0.07^{\mathrm{d}}$ \\
Methionine & $2.70 \pm 0.01^{\mathrm{b}}$ & $3.40 \pm 0.04^{\mathrm{a}}$ & $2.50 \pm 0.01^{\mathrm{c}}$ & $2.30 \pm 0.02^{\mathrm{d}}$ \\
Lysine & $6.41 \pm 0.41^{\mathrm{b}}$ & $6.87 \pm 0.34^{\mathrm{a}}$ & $5.80 \pm 0.53^{\mathrm{c}}$ & $5.60 \pm 0.06^{\mathrm{d}}$ \\
Arginine & $5.80 \pm 0.06^{\mathrm{b}}$ & $6.40 \pm 0.08^{\mathrm{a}}$ & $5.38 \pm 0.05^{\mathrm{c}}$ & $4.77 \pm 0.07^{\mathrm{d}}$ \\
Valine & $2.60 \pm 0.01^{\mathrm{b}}$ & $3.70 \pm 0.04^{\mathrm{a}}$ & $2.20 \pm 0.01^{\mathrm{c}}$ & $2.20 \pm 0.01^{\mathrm{c}}$ \\
Isoleucine & $2.50 \pm 0.01^{\mathrm{c}}$ & $4.50 \pm 0.13^{\mathrm{a}}$ & $2.80 \pm 0.03^{\mathrm{b}}$ & $2.51 \pm 0.01^{\mathrm{c}}$ \\
Histidine & $1.80 \pm 0.02^{\mathrm{b}}$ & $2.41 \pm 0.04^{\mathrm{a}}$ & $1.60 \pm 0.03^{\mathrm{c}}$ & $1.50 \pm 0.01^{\mathrm{d}}$ \\
Non-essential amino acids & & & & \\
Aspartic acid & $3.51 \pm 0.02^{\mathrm{b}}$ & $4.73 \pm 0.05^{\mathrm{a}}$ & $3.56 \pm 0.05^{\mathrm{b}}$ & $3.38 \pm 0.02^{\mathrm{b}}$ \\
Serine & $3.07 \pm 0.05^{\mathrm{b}}$ & $4.20 \pm 0.01^{\mathrm{a}}$ & $3.21 \pm 0.01^{\mathrm{b}}$ & $3.04 \pm 0.05^{\mathrm{b}}$ \\
Glutamic acid & $4.91 \pm 0.02^{\mathrm{b}}$ & $5.91 \pm 0.02^{\mathrm{a}}$ & $4.80 \pm 0.01^{\mathrm{c}}$ & $4.50 \pm 0.01^{\mathrm{d}}$ \\
Glycine & $6.13 \pm 0.03^{\mathrm{b}}$ & $7.03 \pm 0.20^{\mathrm{a}}$ & $5.40 \pm 0.01^{\mathrm{c}}$ & $5.30 \pm 0.01^{\mathrm{c}}$ \\
Alanine & $4.70 \pm 0.01^{\mathrm{c}}$ & $5.80 \pm 0.13^{\mathrm{a}}$ & $4.80 \pm 0.11^{\mathrm{b}}$ & $4.60 \pm 0.10^{\mathrm{d}}$ \\
Tyrosine & $2.50 \pm 0.02^{\mathrm{b}}$ & $3.61 \pm 0.06^{\mathrm{a}}$ & $2.40 \pm 0.02^{\mathrm{b}}$ & $2.37 \pm 0.26^{\mathrm{b}}$ \\
\hline
\end{tabular}

Values (mean \pm 1 SEM, $\mathrm{n}=3$ ) with different superscript letters denote significant difference (ANOVA, HSD; $p<0.05$ ).

This study demonstrated that tubificid worms can be cultured commercially on a fish farm by using a mixture of $40 \%$ mustard oil cake, $30 \%$ wheat bran and $30 \%$ mud for a duration of 42 days. Slaughtered cattle blood can be used as a wetting medium to increase the yield of tubificid worms. The culture system was renewed with $50 \mathrm{mg} / \mathrm{cm}^{2}$ of media ingredients 
once in the first 2 weeks and twice in the remaining 4 weeks. Tubificid worms contain high levels of all essential amino acids and are suitable to be fed to fish that requires high protein.

\section{Acknowledgements}

The authors wish to thank Ministry of Education, Govt. of the People's Republic of Bangladesh for financial support to conduct this study. They are grateful to Alhaj Firoz Khan, Proprietor, Maa Fatema Fish Hatchery, Jessore, Bangladesh for providing land for the construction of the tubificid worm culture systems and continuous water supply.

\section{References}

Ahmed, M. T. and M. F. A. Mollah. 1992. Effects of various levels of wheat bran and mustardoil cake in the culture media on tubificid production. Aquaculture 107: 107-113.

Cheng, C.R., J.T. Wan, T. Han, X.Y Li, Y.D. Jiang and X.B. Wen. 2016. Effects of different dietary amino acid patterns on growth performance and body composition of juvenile giant croaker Nibea japonica. Aquacult. Res. 47: 3942-3951.

FRSS. 2016. Fisheries Statistical Yearbook of Bangladesh. Fisheries Resources Survey System (FRSS), Department of Fisheries, Bangladesh. 32: 57.

Hasan, M. 2003. Growth and feed utilization of tilapia (Oreochromis niloticus Linn.) fed with different protein sources with and without vitamin. Dhaka Univ. J. Biol. Sci. 12: 105-113.

Hossain A., M.F.A. Mollah and M. Hasan. 2012. Ratio optimization of media ingredients for mass culture of tubificid worms (Oligochaeta, Tubificidae) in Bangladesh. Asian Fish. Sci. 25: $357-$ 368.

Huq, S.M.I. and M.D. Alam. 2005. A Handbook on Analyses of Soil, Plant and Water. BangladeshAustralia centre for environmental research. University of Dhaka, Bangladesh $246 \mathrm{pp}$.

Islam S., M.M. Rahman, Mariom, F.A. Mollah and M.A.B. Siddik. 2015. Performance of chicken blood for the production of tubificid worms as live food for fish. World Appl. Sci. J. 33: 496502 .

Khan, M. A. and Abidi, S. F. 2014. Dietary histidine requirement of singhi, Heteropneustes fossilis fry (Bloch). Aquacutl. Res. 45(8): 1341-1354.

Mandal R. N., S. Kar, D. N. Chattopadhyay, J. Maity, B. N. Paul, P. P. Chakrabarti and P. Jayasankar. 2016. Tubifex production using agro-industrial wastes and raw cattle dung. J. Appl. Aqua. 28: 70-75.

Mandal R.N., S. Kar, P.P. Chakrabarti, D.N. Chattopadhyay, B.N. Paul, S. Adhikari, J. Maity and B.R. Pillai. 2018. Production of tubifex - a new dimension of aquaculture in feeding juvenile fish. Aquacult. Asia 22: 20-24.

Mariom and M.F.A. Mollah. 2012. Development of a suitable culture medium for the production of tubificid worms. Asian Fish. Sci. 25: 40-51.

Mariom and M.F.A. Mollah. 2013. Effects of culture space on the production of tubificid worms (Oligochaeta, Naididae). Asian Fish. Sci. 26: 222-231. 
Mollah M.F.A., K. Mosharaf and Mariom. 2012. Selection of suitable media and intervals of media inoculation for culturing tubificid worms. J. Bangladesh Agric. Univ. 10: 325- 330.

Mollah, M.F.A., M.S.A. Mamun, M.N. Sarowar and A. Roy. 2009. Effects of stocking density on the growth and breeding performance of broodfish and larval growth and survival of shol, Channa striatus (Bloch). J. Bangladesh Agric. Univ. 7: 425-430.

Sarker A.K., D. Saha, H. Begum, A. Zaman and M.M. Rahman. 2015. Comparison of cake compositions, pepsin digestibility and amino acids concentration of proteins isolated from black mustard and yellow mustard cakes. AMB Express 5: 22.

Tacon G.J.A. 1987. The Nutrition and Feeding of Farmed Fish and Shrimp - A Training Manual 1. The Essential Nutrients. Food and Agriculture organization of the United Nations. 22-23 pp.

(Revised copy received on 22 July, 2019) 